\title{
O ecumenismo no horizonte do Concílio Vaticano II
}

Elias Wolff

\section{Resumo}

O pontificado de João XXIII inaugura a mudança da Igreja Católica diante do já existente Movimento Ecumênico e do diálogo com as religiões não cristãs. A própria celebração do Concílio torna-se, em ato, um evento ecumênico e de diálogo inter-religioso, pois conta com a presença de observadores não católicos que colaboram com questões e observações que viriam, mais tarde, a integrar os documentos conciliares: Lumen Gentium, Dei Verbum, Sacrosanctum Concilium, Orientalium Ecclesiarum, Dignitatis Humanae, Nostra Aetate, Unitatis Redintegratio e, por fim, a Gaudium et Spes. Às vésperas da celebração dos cinquenta anos de convocação do Concílio, faz-se mister analisar as evoluções, as ações pastorais, as frustrações e as desilusões nesse campo.

Palavras-chave: Concílio do Vaticano II, Ecumenismo, Ações Pastorais, Diálogo Inter-religioso.

\section{Abstract}

The pontificate of John XXIII inaugurated the change of the Catholic Church before the existing ecumenical movement and dialogue with non-Christian 
religions. The celebration of the Council itself becomes, in actuality, an ecumenical event and inter-religious dialogue, as has the presence of non-Catholic observers who collaborate with questions and comments to come later to join the council documents: Lumen gentium, Dei Verbum, Sacrosanctum Concilium, Orientalium Ecclesiarum, Dignitatis Humanae, Nostra Aetate, Unitatis Redintegratio, and finally, Gaudium et Spes. On the eve of the celebration of fifty years of convoking the council, implies the need to analyze trends, pastoral actions, the frustrations and disappointments in this field.

Keywords: Council Vatican II, Ecumenism, Pastoral Actions, Dialogue Inter-religions.

\section{Introdução}

Refletir sobre o ecumenismo na Igreja católica implica refletir sobre a auto-consciência dessa Igreja a partir do Concílio Vaticano II (1962-1965). Primeiro, porque o Vaticano II propôs uma renovação do catolicismo, em sua teologia, suas estruturas, sua ação pastoral. Segundo, porque nessa renovação é que o ecumenismo tem lugar, seja como causa, seja como conseqüência da renovação. O Concílio foi um ato ecumênico em si mesmo e não é possível compreendê-lo sem considerar esse fato. E o ecumenismo, a partir do Concílio, tornou-se uma forte expressão do ser e do agir de muitos cristãos católicos. Existe uma intrínseca relação entre Concílio Vaticano II e ecumenismo, o que permite afirmar que somente onde o Concílio foi assumido de modo efetivo é que o ecumenismo ganhou espaço no jeito de a Igreja católica ser e agir. Ali, houve abertura para o diálogo com as diferentes tradições eclesiais, religiosas e culturais, tanto no âmbito local quanto no âmbito universal.

\section{O status quaestionis da divisão cristã}

O mundo cristão é caracterizado por um universo quase ilimitado de comunidades que buscam afirmar a legitimidade da profissão da fé cristã a partir de seus próprios horizontes de compreensão e vivência, criando tradições teológicas, doutrinais, espirituais e pastorais que configuram o atual pluralismo eclesial. Essa realidade apresenta situações conflitantes e contraditórias, onde comportamentos de rejeição e resistência, escolhas preferenciais, caminhos autônomos, paralelos e por vezes reducionistas, de apologia 
e proselitismo, convivem com iniciativas de aproximação, diálogo e cooperação. O clima de desconfiança geral faz com que as relações entre Igrejas e cristãos sejam extremamente frágeis.

Essa situação tem as marcas da história. A dificuldade para curar a memória de perseguição, marginalização e exclusão mútuas explicam, ao menos em parte, porque os costumes e a linguagem das Igrejas frequentemente assumem conotações polêmicas na relação entre elas. De um lado, o catolicismo ainda não se livrou totalmente do complexo triunfalístico, de poder, em decorrência do longo período da sua hegemonia política em relação às Igrejas e religiões. De outro lado, na relação com os católicos setores do protestantismo conservam traços da apologética polêmica do período da Reforma, ou desenvolvem ações proselitistas para se afirmarem em sua identidade. O comportamento psicológico consequente produz preconceitos e ignorâncias recíprocas.

Nesse contexto, aprofundar a compreensão da própria identidade eclesial significa, para muitos, fortalecer elementos de auto-defesa e de oposição acima dos elementos de convergência e aproximação. Foi desse modo que historicamente as Igrejas construíram separadamente suas estruturas, suas teologias, suas espiritualidades e seus métodos de evangelização. Entre os elementos que caracterizam a divisão atual, destacam-se:

1) Estruturas eclesiais - não há consenso sobre o que é a Igreja e como deve ser sua manifestação histórica para que ela seja coerente com o ensinamento de Jesus Cristo. O dissenso manifesta-se tanto sobre quais são os elementos estruturais da Igreja, quanto sobre a compreensão teológica que se tem deles. Não é fácil um acordo sobre quais estruturas eclesiais nascem de circunstâncias históricas das comunidades e são apenas funcionais, e quais poderiam ter origem na vontade de Cristo - de iure divine. Na eclesiologia católica, uma comunidade eclesial que não tenha esses elementos terá dificuldade para ser reconhecida como uma forma histórica legítima de Igreja cristã. Suas estruturas não configuram a Igreja no sentido próprio do termo e as transformações e pluralismo são vistas como perdas da unidade.

2) Teologia - as Igrejas estão divididas na interpretação do kerigma cristão e dos elementos que constituem a natureza e o conteúdo da fé, como a doutrina da graça, os sacramentos, a natureza da Igreja, os ministérios, entre outros. Compreensões divergentes da fé cristã sustentam as diferentes tradições eclesiais.

3) Espiritualidade - a compreensão da fé e a vida eclesial são alimentadas por espiritualidades diferentes no interior de cada tradição eclesial. Esse fato - que 
poderia ser apenas manifestação da diversidade da atuação do Espírito - num contexto de divisão manifesta o distanciamento de uma tradição eclesial em relação às outras. Assim, as formas litúrgicas, as devoções populares, a celebração dos sacramentos, são também consolidação de tradições teológicas, eclesiais e pastorais em oposição e confronto.

4) Pastoral - as divergências nos tópicos acima leva as Igrejas a se dividirem quanto ao conteúdo e ao método da evangelização. $\mathrm{O}$ anúncio do Evangelho sofre dilacerações causadas pela identidade eclesial de quem o anuncia, fazendo com que o ouvinte tenha dificuldades de acolher a mensagem cristã na sua pureza e integridade.

5) Ética - existem também divisões no horizonte da ética e dos costumes, tanto na sua origem quanto na sua expressão. Para os católicos, o ensinamento do magistério é normativo no comportamento ético. No protestantismo, a ética centra-se na Bíblia, mas com valor na consciência singular e não universal. Assim, estas vêem a ética católica como obediência a uma lei imutável escrita na natureza e no dogma; e os católicos compreendem a ética protestante como individualista e independente do ditado evangélico. Essa é a razão de fundo das diferenças na orientação da família, da sexualidade, da pesquisa científica, etc.

6) Questões sócio-políticas - não há consenso entre as Igrejas na compreensão da sociedade e no modo de situar-se nos conflitos que nela ocorrem. Explicitam-se aqui as divergências éticas e políticas, o que influencia diretamente tanto na organização da Igreja quanto na evangelização. Essas divergências incidem no complexo social agravando ainda mais a situação da divisão cristã.

Esses fatores de divisão mantém as Igrejas numa atitude de criticismo reacionário e violento na relação entre elas. Abrir caminhos de encontro, diálogo e cooperação intereclesial, visando a restauração histórica da unidade cristã através de um diálogo que possua conteúdo, método e finalidade comuns, é algo que parece extrapolar os limites das possibilidades atuais na maioria dos ambientes eclesiásticos. Leituras recíprocas sumárias do costume eclesial e teológico parecem impedimentos insuperáveis a um diálogo que busque convergência e consenso. 


\section{A posição católica}

\section{a) Do exclusivismo triunfalista}

Emerge aqui a questão sobre como o catolicismo compreende e se posiciona no contexto do pluralismo eclesial. De Constantino às vésperas do Concílio Vaticano II, ele afirmou-se com base a princípios de autoridade e autosuficiência. Esses princípios, alicerçados no ministério petrino e na hegemonia política, criou uma eclesiologia exclusivista e triunfalista. Sozinha, a Igreja romana compreendia representar a totalidade da fé cristã, destituindo de qualquer significação elementos cristãos situados além de suas estruturas. A partir do século XVI, a eclesiologia da "sociedade perfeita" sustentou essa posição em dois principais fatores: o sistema tridentino, que orientava a organização eclesial, a teologia e a ação pastoral; e o princípio teológico de que Cristo fundou a Igreja como sociedade autônoma e completa, identificando a Igreja de Cristo com a organização eclesiástica romana. Consequentemente, não há possibilidade salvífica fora desta ${ }^{2}$. Com base nesses princípios, ela manteve-se, por muito tempo, num confronto polêmico com as outras tradições eclesiais.

Isso influencia no seu posicionamento ecumênico. Inicialmente, houve a rejeição tácita do movimento ecumênico originado no meio protestante, por compreender que não são os encontros de diálogo que constroem a verdadeira Igreja de Cristo. Reiteradas vezes as autoridades eclesiásticas recusaram o convite para participarem das iniciativas ecumênicas. Entre outras: em 1910, pela ocasião da Conferência de Edimburgo e em 1948, na assembléia de fundação do Conselho Mundial de Igrejas ${ }^{3}$ (a primeira vez que a Igreja romana enviou delegados oficiais num encontro ecumênico foi em 1961, na assembléia do Conselho Mundial de Igrejas, em Nova Delhi). E sendo a Igreja romana a Igreja de Jesus Cristo organizada como "sociedade perfeita", o diálogo com os cristãos situados além das suas fronteiras institucionais era valorizado em vistas do "retorno" destes ao

\footnotetext{
${ }^{1}$ Sistematizada, sobretudo, pelo professor do Colégio Romano, Roberto Belarmino (1542-1621) em Opera omnia (Napoli 1851-1861, 7 vols; Paris 1870-1876, 12 vols

${ }^{2}$ Tal foi a interpretação do axioma extra ecclesiam nulla salus est em documentos eclesiais, como: o Concílio de Florença-Ferrara (1438-1445) e a encíclica Mortalium animos, de Pio XI (1928).

${ }^{3}$ Por essa razão, “o Santo Ofício, em decreto de 8 de julho de 1928, à consulta: "se é permitido aos católicos assistirem, ou interessarem-se por reuniões, agrupamentos, conferências, ou sociedades de não católicos, que tenham por objetivo reunir sob um só pacto religioso (uno religionis fodere) todos aqueles que de alguma forma reivindicam o nome de cristãos" (DH 2199)... a resposta é um redondo non licet" (RochA, Z.B., "Ecumenismo: avanços e recuos", Revista Eclesiástica Brasileira, 241 (2001) 85-100. Aqui, 87).
} 
seio das suas estruturas ${ }^{4}$. Em 1928, em sua encíclica Mortalium animos, Pio XI escrevia sobre os encontros ecumênicos no meio protestante: "a Sé Apostólica não pode de modo algum participar das suas reuniões, e de nenhum modo os católicos podem aderir ou ajudar tais tentativas". Assim, "ecumenismo" diz respeito apenas à conservação da integridade da fé católica romana.

\section{b) Às iniciativas de aproximação e diálogo}

Mas nem tudo e nem todos na Igreja católica desse período foi anti-ecumênico. A situação de distanciamento oficial do movimento ecumênico não impediu o surgimento de vozes e iniciativas ecumênicas que aos poucos vão penetrando nos meios católicos. Alguns exemplos: a) na reflexão teológica, o ponto de partida é a obra de J. Y.M.. Congar, Chrétiens Désunis. Principes d'un "oecuménisme" catholique (1937). Na mesma direção estão K. Rahner, e J. Danielou, apenas para citar os que mais influência tiveram no Concílio Vaticano II. b) Na espiritualidade, em 1937 o padre Paul Couturier (1881-1953), junto com Paul Wattson (1863-1940) fortalece a "Semana de Oração pela Unidade dos Cristãos"; o monge beneditino Lambert Beauduin (1873-1960) fundou, em 1925, os “monges da união", na Bélgica, e em 1939 a revista Irenikon, ainda hoje uma das principais nos meios ecumênicos. c) Uma série de organismos ecumênicos surgem pela iniciativa de católicos, como o Centro Istina (Paris), o movimento Una Sancta (Alemanha), o Centro Pro Unione (Roma). d) Na busca do diálogo estável, entre os anos 1921 a 1925, um grupo de teólogos anglicanos e católicos desenvolveram conversações doutrinais (Malines) de fundamental importância para a unidade das duas Igrejas. e) $\mathrm{Na}$ ação social, cristãos de diferentes Igrejas solidarizaram-se nos esforços pela promoção humana, sobretudo durante os dois grandes conflitos mundiais. Essas iniciativas, entre outras, estão na base do primeiro pronunciamento oficial do magistério católico que apresenta abertura para compreender o movimento ecumênico como "inspiração da graça do Espírito Santo".

Mas é mesmo na década de 60 que as mudanças se fazem sentir, quando líderes eclesiásticos se posicionam corajosamente em relação ao ecumenismo.

\footnotetext{
${ }^{4}$ Ver, entre outros documentos, as encíclicas Praeclara gratulationis (1894) e Satis Cognitum (1896), de Leão XIII; Ex quo (1926) e Pascendi dominici gregis (1907), de Pio X; Mortalium animos (1928), de Pio XI; e Mystici corporis (1943), de Pio XII.

${ }^{5}$ Citado por Vercruysse, Jos. E., Introduzione alla Teologia Ecumenica, Casale Monferrato, PIEMME, 1992, 64.

${ }^{6}$ Instrução do Santo Ofício, De motione ecumenica, de 20/12/1949.
} 
Durante os nove anos em que foi visitador apostólico na Bulgária (1925-1934), o bispo Angelo Roncalli (depois Papa João XXIII) buscou realizar uma "missão de paz" nas relações com muçulmanos, a maioria ortodoxa e a minoria católica de rito latino e oriental. Em 1927, visitou o patriarca de Constantinopla, Basílio III, acreditando que a unidade exige "a caridade ... mais do que a discussão teológica”. Depois, como delegado apostólico na Grécia e Turquia (entre 1934 a 1944) e como núncio em Paris (1944-1953) continuou o esforço de boas relações entre Igrejas e religiões. Apenas três meses após ter sido eleito papa, em 1958, João XXIII convocou um concílio que teria o ecumenismo como "um de seus principais objetivos" (UR 1). Em 1960, o mesmo papa criou o Secretariado para a Unidade dos Cristãos, convidou observadores ortodoxos, anglicanos e protestantes para o Concílio Vaticano II, aprovou a presença de uma delegação de católicos na assembléia do Conselho Mundial de Igrejas em Nova Delhi (1961), e retirou as expressões anti-semitas da liturgia da Sexta-Feira Santa.

Como sucessor do papa Roncalli, o papa Paulo VI deu continuidade ao Concílio Vaticano II, intensificando os esforços pela justiça e pela paz entre os povos e pela unidade dos cristãos. Por entender a divisão dos cristãos como um dos "mais graves problemas" do cristianismo e da humanidade, estabeleceu contatos com os líderes eclesiásticos protestantes, anglicanos e ortodoxos, visitou organismos ecumênicos (como o Conselho Mundial de Igrejas, em 1969), enfatizou a responsabilidade ecumênica dos bispos católicos romanos e incentivou as semanas de oração pela unidade dos cristãos. A primeira encíclica do papa Paulo VI, Ecclesiam Suam (1964) foi o primeiro documento da Igreja Católica Romana a colocar o diálogo no centro da auto-consciência eclesial e da tarefa evangelizadora. Aqui, o diálogo intereclesial aparece no contexto do diálogo com as religiões e com o mundo. O mesmo papa confirmou esses três horizontes do diálogo (ecumênico, interreligioso e cultural) nos documentos conciliares, especificamente em Unitatis Redintegratio, Orientalium ecclesiarum, Nostra Aetate, Dignitatis humanae, Ad Gentes e Gaudium et Spes.

Esses testemunhos são suficientes para indicar a mudança na Igreja católica em relação às outras Igrejas e ao movimento ecumênico. O Concílio confirmaria essa mudança, apresentando um novo modo de a Igreja ser, configurada por uma identidade relacional e sem os exclusivismos ou ares de auto-suficiência que a caracterizavam até então. Na mesma direção segue João Paulo II, ao afirmar que os cristãos devem "professar juntos a mesma verdade sobre a Cruz" (UUS 1) 7 .

${ }^{7}$ João Paulo II, Carta encíclica Ut Unum Sint, Paulinas, 1996. 
O próprio papa se propõe a "promover todo e qualquer passo útil ... para que a unidade dos cristãos cresça até chegar à plena comunhão" (UUS 2), afirmando que a causa da unidade "é um compromisso bem próprio do Bispo de Roma" (UUS 4).

O papa Bento XVI afirmou em seu primeiro discurso de 20 de abril de 2005 aos cardeais eleitores:

“... com plena consciência, no início do seu ministério na Igreja de Roma, na qual Pedro derramou o seu sangue, o atual Sucessor assume como compromisso primário o de trabalhar sem poupar energias na reconstituição da plena e visivel unidade de todos os seguidores de Cristo. Esta é a sua ambição, este é o seu impelente dever. Ele está consciente de que para isso não são suficientes as manifestações de bons sentimentos. São necessários gestos concretos que entrem nos corações e despertem as consciências, enternecendo cada um àquela conversão interior que é o pressuposto de qualquer progresso pelo caminho do ecumenismo".

Mas os tempos agora são outros. Esse pontificado é marcado por fatores conjunturais do catolicismo que freiam consideravelmente o impulso ecumênico do Concílio. É verdade que tal situação iniciou-se já com João Paulo II, tendo como principal assessor o então Cardeal Ratzinger. Desde então, muitos pronunciamentos e gestos ecumênicos de líderes eclesiásticos católicos perdem força e visibilidade.

\section{O Concílio Vaticano II (1962-1965)}

No dia 25 de janeiro de 1959, o papa João XXIII anunciou na Basílica de São Paulo Fora dos Muros a realização do Concílio Vaticano II, com os objetivos do bem espiritual dos cristãos e a unidade das Igrejas. É significativo o fato de que o anúncio do Concílio aconteceu no final da semana de oração pela unidade dos cristãos ${ }^{8}$. A presença e atuação dos observadores delegados de diferentes tradições cristãs (38 na primeira sessão, e 168 ao longo do Concílio), e a consulta feita às Igrejas para que enviassem suas observações sobre os temas tratados, contribuíram para que o Concílio fosse realmente um ato ecumênico.

\footnotetext{
${ }^{8}$ Alberigo, Giuseppe, org., História dos Concílios Ecumênicos, Paulus, 1995, 394. Mas a convocação formal do Concílio ocorreu mesmo em 25 de dezembro de 1961, com a constituição apostólica Humanae salutis, e a sessão solene de abertura em 11 de outubro de 1962.
} 
O Concílio colocou um novo olhar sobre o pluralismo eclesial e a situação de divisão entre os cristãos, buscando responder de modo consequente às interpelações que essa realidade apresenta. $\mathrm{O}$ ecumenismo é compreendido como o caminho mais coerente nesse processo.

\section{a) O Decreto Unitatis Redintegratio}

Uma das maiores expressões conciliares desse fato é o Decreto sobre o Ecumenismo, Unitatis Redintegratio (UR) ${ }^{9}$, declarando ser a busca da unidade entre todos os cristãos um dos objetivos principais do Concílio (UR 1). O Decreto estabelece as bases doutrinais e orientações pastorais para o ecumenismo na Igreja Católica Romana e apresenta-se em três capítulos: a) "Princípios católicos do ecumenismo", tratando da teologia e reconhecendo o movimento ecumênico como fruto da graça do Espírito Santo (UR 2-4); b) "A prática do ecumenismo" (UR 5-12), dando força sobretudo ao ecumenismo espiritual (UR 8-9) e à cooperação (UR 12); c) "As Igrejas e Comunidades Eclesiais separadas da Sé Apostólica Romana", buscando maior compreensão e relacionamento entre os cristãos, estabelecendo considerações diferentes entre as Igrejas do Oriente (UR 14-18) e as do Ocidente (UR 19-23).

$\mathrm{O}$ ensinamento conciliar incentiva todo tipo de iniciativa que favoreça à unidade, fortalecendo quatro elementos: a) o ecumenismo como uma atitude, com um comportamento dialogante frente às diferentes Igrejas, eliminando palavras, juízos e ações que não correspondam à condição dos irmãos separados (UR 4); b) o diálogo teológico, para aprofundar a doutrina cristã nas várias confissões, distinguindo o "conteúdo" e as "formas" de explicitação das verdades da fé (UR 9.11), e compreendendo que existe uma "hierarquia das verdades", que mostra "o diverso nexo com o fundamento da fé cristã" (UR 11); c) a cooperação prática, que favorece a corresponsabilidade das Igrejas em iniciativas pastorais concretas (UR 12); d) o ecumenismo espiritual, considerando a oração "a alma de todo o movimento ecumênico" (UR 8).

Assim, na consciência conciliar existe um "imperativo ecumênico", como um apelo permanente à unidade. Os padres conciliares compreendem que a situação de divisão cristã impele à urgência do diálogo. A partir do Concílio afirma-se que: a) apesar da divisão causada pelo pecado, a Igreja de Cristo continua una em sua essência divina e espiritual (UR 4); b) os cristãos das diferentes tradições eclesiais mantém laços de unidade com a única Igreja,

\footnotetext{
${ }_{9}^{9}$ Publicado em 21 de novembro de 1964 in AAS 57 (1965) 90-107.
} 
pela presença nelas de elementos que Cristo deu à sua Igreja (UR 3; UUS 11.13), razão da existência de um "patrimônio comum" (UR. 3.4; UUS 47); c) o valor da contribuição das diferentes Igrejas na evangelização (UUS 98); d) a unidade é buscada pela oração comum, o consenso teológico e a cooperação a favor da evangelização e do bem comum na sociedade (UR 8-12; UUS 43).

Com isso, a Igreja romana conscientiza-se que é em Deus que deve acontecer a "íntima comunhão", e é na condição de "instrumento" e "sacramento" que ela contribui para isso (LG 1). Portanto, a comunhão vai além do caráter histórico das estruturas da Igreja e através delas, impedindo absolutizações. Na perspectiva da salvação do mundo, a Igreja não pode sentir-se como uma realidade voltada para si mesma, mas aberta ao Reino de Deus, o mistério da redenção que envolve todas as confissões cristãs.

\section{b) As estruturas a serviço da unidade}

A realização do ideal da unidade exige condições estruturais que possibilitem sua concretude, destacando-se:

\section{- O Conselho Pontificio para a Promoção da Unidade dos Cristãos}

No dia 05 de junho de 1960, o papa João XXIII instituiu o Secretariado para a Unidade dos Cristãos para ajudar a Igreja católica a melhor integrar-se nos caminhos do diálogo ecumênico, contribuindo para que todos os cristãos encontrem "mais facilmente a estrada para alcançar aquela unidade pela qual Cristo rezou"10. A atuação desse Secretariado foi fundamental para colocar o ecumenismo em foco no Concílio. Ele foi responsável pelas conversações com as Igrejas para que enviassem seus representantes no Concílio e para que enviassem também suas observações sobre os temas a serem estudados. A ele coube a responsabilidade dos documentos pastorais promulgados pelo Concílio sobre ecumenismo, liberdade religiosa, relações da Igreja com as religiões e divina revelação, este último preparado conjuntamente com a comissão teológica. Após o Concílio, em 3 de janeiro de 1966, o papa Paulo VI confirmou o Secretariado como instituição permanente da Cúria Romana, especificando sua estrutura e competências. O Secretariado foi também responsável pelas relações religiosas da Santa Sé com os hebreus, criando o comitê internacional de relações entre católicos e hebreus. Em 1989, o papa João Paulo II reestruturou o Secretariado dando-lhe o nome de Pontificio Conselho para a Promoção da Unidade dos Cristãos.

\footnotetext{
${ }^{10}$ Citado por Stransky, Tom., "Pontificio Consiglio per la Promozione dell'Unità dei Cristiani", in Dizionario del Movimento Ecumenico, Bologna, EDB, 1994, 860.
} 


\section{- As comissões de diálogo}

A partir das relações oficiais estabelecidas com as Igrejas, formaram-se comissões (bilaterais e multilaterais) de diálogo com organismos representantes das mais diferentes tradições eclesiais. Em nossos dias, consolidou-se, no nível nacional e internacional, uma vasta rede de diálogos bilaterais e multilaterais, envolvendo quase todas as Igrejas. Esses diálogos são de duas principais naturezas: são diálogos eclesiais oficiais, porque autorizados pelas respectivas autoridades eclesiásticas, que nomeam delegados; tratam de questões doutrinais, buscando superar as divergências na compreensão e vivência da fé no Evangelho e na Igreja. Atualmente, a Igreja católica participa de 70 dos 120 Conselhos de Igrejas existentes no mundo; em 14 Conselhos Nacionais e em 3 dos 7 Conselhos Regionais. Além disso, ela compõe 16 comissões de diálogo tratando das mais variadas questões, como autoridade na Igreja, Eucaristia, ministérios, eclesiologia, etc ${ }^{11}$, das quais destacamos:

- Com o Conselho Mundial de Igrejas: iniciado em 1966, o diálogo teológico acontece com o departamento de Fé e Constituição. Publicações: Batismo, Eucaristia e Ministérios (1982); A Confissão da Fé Apostólica (1991) a Formação Ecumênica (1993) Tesouro em Vasos de Barro (1998), A Natureza da Igreja (2006).

- Com os Ortodoxos: 1) Calcedonenses: após o fracasso das tentativas de união nos Concílios de Lião (1274) e Florença (1439), as relações foram retomadas de vez com o encontro entre o papa Paulo VI e o patriarca Atenágoras I, em 1965. Entre os anos 1972 a 1977, vários encontros de teólogos publicaram uma reflexão sobre os ministérios. Mas foi apenas em 1982 que se publicou o primeiro documento conjunto, O mistério da Igreja à luz da eucaristia e da Santíssima Trindade. Depois, publicou-se documentos sobre: fé, sacramentos e unidade da Igreja (1987); o sacramento da Ordem e a estrutura sacramental da Igreja (1988); o uniatismo, método da união do passado e a atual busca da unidade (1993). Em 2007 publicou-se um estudo comum sobre Conseqüências eclesiológicas e canônicas da natureza sacramental da Igreja. 2) Orientais (não calcedonenses): houve uma primeira comissão com os Coptas, formada a partir do encontro do papa Paulo VI com o papa Shenuda III, em 1973. Em 1974, publicou-se um relatório conjunto sobre cristologia; em 1975, sobre a unidade a que se busca; em 1976, retornou-se ao estudo dos "princípios do

${ }^{11}$ Os resultados dos trabalhos das comissões no nível internacional, encontram-se em Enchiridion Oecumenicum, Bologna, EDB, vol. I, 1988 e vol. III, 1995. 
diálogo".Em 1988, publicou-se uma fórmula que exprime o acordo oficial sobre cristologia, e em 1990, iniciou-se um estudo sobre o Filioque. 3) Sírios ortodoxos: o principal resultado do diálogo foi a declaração conjunta sobre cristologia, em 1984. 4) Siro-malankaresi: em 1990, publicou-se um acordo doutrinal cristológico, e no mesmo ano um relatório provisório sobre o matrimônio e a comunhão eucarística.

- Com a Federação Luterana Mundial: iniciado em 1966, o diálogo está em sua quarta fase, com a publicação de 12 documentos, entre os quais: primeira fase, 1967-1972 - O Evangelho e a Igreja; segunda fase, 1973-1978 A Ceia do Senhor; terceira fase, 1986-1993 - A Igreja e a Justificação; quarta fase, 1994-1999 - Declaração conjunta sobre a doutrina da Justificação.

- Com o Conselho Metodista Mundial: iniciado em 1967, esse diálogo publicou cinco documentos, desde o Relatório de Denver, em 1971, até $A$ tradição apostólica, em 1991. O último trabalho da Comissão Católica-Metodista foi a publicação do documento, em 2006, A graça que vos foi dada em Cristo, que implica em estudos sobre eclesiologia, a serem realizados na atual fase do diálogo. Também em 2006, o Conselho Metodista Mundial aderiu à Declaração conjunta sobre a Doutrina da Justificação, já acordada entre a Igreja católica e a Federação Luterana Mundial.

- Com a Comunhão Anglicana: o ponto de partida foi o encontro entre o papa Paulo VI e o arcebispo de Cantuária, Michael Ramsey (Roma, 1966). Em 1970, formou-se a Comissão Internacional Católica Anglicana. Dentre os documentos publicados, destacam-se a declaração sobre a Doutrina eucarística (1971), o Ministério e a Ordenação (1973) e Autoridade na Igreja (I, 1976; II, 1981; III, 1998).

- Com os Reformados: entre os anos 1970 a 1977, refletiu-se sobre $A$ presença de Cristo na Igreja e no mundo, e entre os anos 1984 a 1990, sobre uma compreensão comum da Igreja. Atualmente, dialoga-se sobre a possibilidade de as Igrejas Reformadas aderirem à Declaração Comum sobre a Doutrina da Justificação, assinada entre católicos e luteranos em 1999 e, em 2006, pela Comunhão Metodista em nível internacional.

- Com os Pentecostais: o diálogo iniciou entre os anos 1969-1971 e tem cinco fases: entre 1972 a 1976, refletiu-se sobre a iniciação cristã e os carismas, as escrituras e a tradição, o culto, o discernimento dos espíritos, 
a oração e o louvor; de 1977 a 1982, refletiu-se sobre a fé e a experiência religiosas, o falar em línguas e o papel de Maria; entre 1985 a 1989, estudo o tema da koinonia; a quarta fase (1990-1997) concluiu com um relatório sobre Evangelização, Proselitismo e Testemunho Comum. A quinta fase de diálogo (1998-2006) publicou o estudo Ser cristão: Escritura e Patrística.

- O Diretório para a aplicação dos princípios e normas sobre o ecumenismo

A partir do Concílio Vaticano II, o então Secretariado para a Unidade dos Cristãos emanou normas e critérios sobre o ecumenismo na Igreja Católica. O principal documento foi o Diretório para a aplicação dos princípios e normas sobre ecumenismo, publicado em etapas: em 1967, tratando das comissões ecumênicas diocesanas e nacionais, o mútuo reconhecimento do batismo, e a comunhão nas coisas espirituais; em 1970, apresentando os princípios e a prática ecumênica na formação em colégios, universidades e seminários; e em 1993, atualizando as mudanças ocorridas no Código de Direito Canônico (1983). O Diretório ecumênico visa "fornecer normas gerais universalmente aplicáveis para orientar a participação católica na atividade ecumênica" (n. 7). É composto por cinco capítulos: as razões da busca da unidade dos cristãos; a organização do serviço da unidade no interior do catolicismo; a formação para o ecumenismo; a comunhão de vida e de atividade espiritual entre os batizados; e a cooperação ecumênica, o diálogo e o testemunho comum. Esses temas são apresentados à luz do Concílio, buscando "reforçar as estruturas que foram já preparadas para manter e orientar a atividade ecumênica a todos os níveis da Igreja" (n. 6).

\section{Principais avanços}

\section{a) Os frutos do diálogo}

Esses fatos mostram a profundidade das transformações ocorridas na relação da Igreja católica com as demais Igrejas. O rosto católico passou a ser um "rosto de irmão"12 para elas, e vice-versa. Os cristãos separados não mais se consideram estranhos, concorrentes ou inimigos, mas "irmãos" e "irmãs", linguagem desconhecida até bem pouco tempo.

\footnotetext{
12 Altmann, Walter, "De que maneira os protestantes entendem a contribuição dos católicos romanos no Brasil”, in Mateus, O.P. org., Teologia no Brasil - Teoria e prática, ASTE, 1985, 199.
} 
Em sua encíclica sobre o ecumenismo, o papa João Paulo II reconhece que é a "primeira vez na história que a ação em prol da unidade dos cristãos assumiu proporções tão amplas e se estendeu a um âmbito tão vasto" (UUS 41). O mesmo papa reconhece também como "frutos do diálogo": a fraternidade reencontrada pelo reconhecimento do único Batismo e pela exigência que Deus seja glorificado na sua obra; a solidariedade no serviço à humanidade; convergências na palavra de Deus e no culto divino; o apreço mútuo dos bens nas diferentes tradições eclesiais; o reconhecimento de que "aquilo que une é mais forte do que o que divide" (UUS 20.41-49).

Esses frutos permitem apontar cinco aspectos de crescimento nas relações ecumênicas: a) nas relações dos dirigentes das Igrejas, existe a localização de pontos de encontro e mútua procura de avizinhamento e diálogo; b) no nível teológico-doutrinal, chegou-se a importantes convergências e consensos sobre vários elementos da fé cristã e eclesial; c) nas comunidades dos fiéis, cresce o convívio entre cristãos de diferentes confissões, vencendo-se preconceitos e hostilidades; d) no campo pastoral, a cooperação ecumênica é realidade em muitos ambientes; e) cresce a sensibilidade ecumênica na espiritualidade.

O catolicismo não é mais o mesmo desde que se integrou nos caminhos ecumênicos. No campo eclesiológico, há espaço para desenvolver a ecumenicidade do ser da Igreja, tanto no plano da interioridade quanto no plano da ação. O ecumênico penetra na consciência e na prática da Igreja, não como "acessório ou apêndice", mas como sua própria "essência" (UUS 9.20). Trata-se de uma tensão à comunhão de todos os cristãos: não mais uns contra os outros (escândalo); não uns sem os outros (deserção); nem mais uns caminhando paralelamente aos outros (divisão). Trata-se de uns com os outros e uns para os outros. O acento não está no fato de os cristãos serem "separados", mas "irmãos". O próprio Concílio foi um exemplo desse "estar com" o outro, pela presença dos observadores ortodoxos, protestantes e anglicanos. Os 16 documentos conciliares - 4 Constituições, 9 Decretos e 3 Declarações mostram a nova visão que a Igreja tem de si mesma, das diferentes Igrejas, das Religiões e do mundo partindo do esse-ad que lhe é constitutivo. Esses documentos são os pontos cardeais do Concílio e são também o método e a hermenêutica da compreensão do ecumenismo na Igreja Católica Romana.

\section{b) Nova eclesiologia}

A nova consciência da Igreja é formada por uma nova compreensão do pluralismo eclesial e pela inserção na "tradição ecumênica", bases para a superação de tendências ao dogmatismo fixista e antidialógico. As afirmações mais significativas 
do Concílio mostram uma nova eclesiologia, eminentemente ecumênica. O ponto fulcral é a compreensão de que a Igreja de Cristo subsistit in, ou seja, está presente na Igreja Católica (LG 8), mas sem uma relação de identificação fechada, como se esta pudesse exaurir aquela. Essa nova auto-consciência coloca fim nas interpretações exclusivistas do axioma extra ecclesiam nulla salus est, e a Igreja compreende que não é ela o centro do cristianismo e da salvação, mas Cristo e seu Reino. Daqui, outras afirmações teológicas já constatadas pelo diálogo intereclesial como pilares da ecumenicidade da Igreja do Concílio: o valor da Sagrada Escritura na vida e doutrina da Igreja (Dei verbum); a eclesiologia do "Povo de Deus" (LG, cap. II); a compreensão da necessidade de renovação contínua da Igreja em sua existência histórica (LG 8; UR 6); a confissão da cruz de Cristo e seu valor na vida dos cristãos e da Igreja em seu conjunto (LG 8; UR 4; GS 37); a compreensão dos ministérios eclesiásticos como serviços (CD 16; PO); o valor do sacerdócio de todos os batizados (LG 10-11; AA). Esses elementos são alicerces da Igreja "sacramento de comunhão" (LG 1), que se configura como "povo de Deus" uno e único, não obstante as diferentes modalidades de pertença a ele (LG 14-16).

E sobre eles assenta-se o ecumênico na Igreja, conferindo-lhe três características fundamentais: a) necessitada de uma renovação contínua (LG 8; UR 6; UUS 15-17), tanto no plano ontológico quanto no plano estrutural. Isso a torna mais fiel à identidade que Cristo lhe conferiu, superando as cristalizações históricas. Esse é também o objetivo do ecumenismo: renovar a Igreja, ajudando-a no aprofundamento da sua auto-consciência, a recompreender-se para reformar-se e reformar-se para reunificar-se. b) Identidade relacional: a Igreja do Concílio não é solitária, sua natureza e missão são compreendidas no horizonte da catolicidade que the é constitutiva, o que a impele ao diálogo ecumênico e interreligioso como algo próprio da sua identidade. Esta identidade manifesta-se a partir da e na relação com o mundo, as Igrejas e as religiões. c) Dialogicidade (UUS 28-30): a Igreja é, constitutivamente, diálogo. Ela se faz diálogo e faz o diálogo. A necessidade do diálogo surge de algo mais profundo do que a simples constatação da realidade do pluralismo eclesial (e religioso/cultural). Vem da profundidade do ser da própria Igreja, como expressão da sua vocação à comunhão que tende a se expandir "para fora" de si mesma.

\section{Sinais de recuo}

Uma leitura apressada da realidade acima apresentada poderia causar um otimismo irrealista em relação aos progressos do ecumenismo no catolicismo romano. Mas, infelizmente, a magnitude ecumênica dos fatos citados nem 
sempre incidem no cotidiano da Igreja. Muitos deles mantém-se isolados, mais vinculados a pessoas e situações do que à Igreja como um todo.

Os sinais de recuo se fazem sentir sobretudo no comportamento da Igreja oficial nos últimos vinte anos. Esse comportamento parece colocar dúvidas sobre o real compromisso ecumênico da Igreja católica. Destacam-se nessa direção alguns documentos emanados pela cúria romana cujos conteúdo e estilo fizeram ressurgir o espírito da polêmica e animosidades entre as Igrejas, com sérias consequências para as relações ecumênicas. No interior do próprio catolicismo houve dissenso acerca desses documentos, por se entender que causam perplexidades. Ao apresentar a doutrina católica sobre a fé cristã e a Igreja, tais documentos não consideram os progressos realizados pelo diálogo ecumênico, que muito têm ajudado as Igrejas na convergência teórica e prática do que é ser cristão hoje.

É um desafio para a Igreja católica de hoje compreender o Concílio Vaticano II como "ponto de partida" para a renovação teológica e eclesial. Para agir no hoje e prever o amanhã, há que se voltar atrás, recuperando os ensinamentos do Concílio. Mas voltar atrás é um método para avançar no caminho, e não o próprio sentido do caminhar... O movimento ecumênico olha o futuro da Igreja. A unidade a ser alcançada se dá pela capacidade criativa de repensar teologicamente e institucionalmente o ser da Igreja. Assim o Concílio é visto como "ponto de partida". Voltar ao Concílio faz-se necessário, mas para ir além. E entre o Concílio e os tempos de hoje não há um espaço vazio. Esse meio foi preenchido pelas relações entre as Igrejas, fecundas em seus resultados, como já observado.

O que se conclui é que nem sempre há, na Igreja católica, sintonia entre o âmbito institucional e o teológico e pastoral sobre questões ecumênicas, entre lideranças eclesiásticas e as comunidades dos fiéis. Não poucas vezes crises e dinâmicas internas assumem precedência em relação ao ecumenismo, o que gera tensão entre o espírito de abertura e diálogo e a necessidade de salvaguardar a própria identidade. Assim, os limites das estruturas eclesiásticas, do pensamento teológico, da espiritualidade, da prática pastoral, etc., influenciam na intensidade do engajamento ecumênico.

Mas isso não significa que a Igreja católica abandonou o ideal da busca da unidade visível da Igreja. Essa é uma conviç̧ão consolidada em muitos ambientes católicos. E se olharmos o Brasil, poucas Igrejas possuem a coragem que a Igreja católica tem para publicar orientações ecumênicas incentivando seus fiéis à participação de eventos ecumênicos. O que se faz necessário é 
um esforço maior para que as convicções ecumênicas apresentadas nos documentos e nos pronunciamentos oficiais possam melhor se articular com a vida concreta das comunidades dos fiéis, fortacelendo-os nas iniciativas de diálogo com membros de outras Igrejas.

\section{Incidências na realidade brasileira}

O clima de diálogo que o Concílio possibilitou à Igreja católica em todo o mundo repercutiu entre seus fiéis no Brasil. Contribuiu para isso o interesse com que alguns bispos brasileiros presentes no Concílio acompanharam as discussões sobre o ecumenismo. Esses compreenderam que Igreja e ecumenismo são realidades intrinsecamente vinculadas. A partir de então, mesmo com alguma resistência em alguns setores católicos, a Conferência Nacional dos Bispos do Brasil (CNBB), afirma que a Igreja busca sua verdade no Evangelho de Cristo através de "um diálogo sempre mais frutuoso com os cristãos não católicos". Todos buscam a fisionomia divino-humana de Cristo na Igreja unida ${ }^{13}$.

Motivada pelas orientações conciliares, a CNBB desenvolve relações ecumênicas com Igrejas do protestantismo, do anglicanismo, da ortodoxia, e busca também diálogo com grupos pentecostais e os não cristãos ${ }^{14}$. $\mathrm{O}$ processo é lento e a intensidade do diálogo não é a mesma com todos os interlocutores. É com as Igrejas integradas na Coordenadoria Ecumênica de Serviços (CESE, 1973) e no Conselho Nacional de Igrejas Cristãs do Brasil (CONIC, 1982), que o diálogo é mais estável e estruturado. Como em outros ambientes, também o episcopado brasileiro sofre com as tensões teológico-pastorais internas o que, de algum modo, influencia nas relações ecumênicas. Contudo, iniciativas são tomadas para a sustentação do diálogo, envolvendo tanto as lideranças eclesiásticas quanto as comunidades dos fiéis. É possível verificar nessas iniciativas os elementos que configuram o empenho ecumênico da CNBB em três principais horizontes:

a) horizonte histórico: no final da década de 60 do século XX, o Secretariado Nacional de Teologia da CNBB, que incluía o "Setor Ecumenismo",

\footnotetext{
${ }^{13}$ CNBB, Comunicado Mensal, jan/fev., 148-149 (1965), 11.

${ }^{14}$ Com as religiões, o diálogo progride no nível oficial com os judeus, sobretudo após a criação da Comissão Nacional Católica-Judáica (1988). Há contatos também com líderes de outras religiões, como o islamismo, o budismo e as religiões afro-brasileiras, entre outras, mas não se chegou ainda à criação de meios que garantam estabilidade a essas relações.
} 
foi o responsável pela divulgação das orientações ecumênicas do Concílio. Os relatórios do "Setor Ecumenismo" do Secretariado apresentam intensas atividades nos regionais e dioceses, com a criação de centros ecumênicos, seminários de estudos, relações com lideranças eclesiásticas e com organismos ecumênicos do país ${ }^{15}$. Buscando dar consistência ao ideal da unidade, criou-se a Linha 5 do Plano Pastoral de Conjunto (1966) e das Diretrizes Pastorais (1975), para tratar especificamente do diálogo ecumênico e interreligioso. Em 1964, a CNBB chegou a pensar na publicação de um Diretório Nacional de Ecumenismo, fato que não aconteceu porque logo recebeu-se de Roma a notícia de que seria publicado um Diretório ecumênico para toda a Igreja.

A partir dos anos setenta, as atividades ecumênicas da CNBB se intensificaram consideravelmente: ela passou a convidar lideranças das Igrejas protestantes, anglicanas e ortodoxas para participarem das suas Assembléias e algumas Reuniões Maiores; em 1973, ajudou a fundar a Coordenadoria Ecumênica de Serviços - CESE; entre os anos 1975-1982, a CNBB participou dos "Encontros de Dirigentes de Igrejas - EDI", que deram origem ao atual CONIC (1982), da qual é membro-fundador; criou comissões de diálogo: em 1974, a Comissão Nacional Católica Romana-Evangélica Luterana; em 1982, a Comissão Nacional Anglicana-Católica Romana. Na década de 80, chegou-se a pensar também em uma Comissão Católica Metodista, o que infelizmente não se efetivou; em 1998, criou a Comissão de Diálogo Católica-Judáica; em 2009, foi criada a Comissão Nacional Católica-Presbiteriana Unida. Há algum tempo vem tentando formar núcleos de diálogo com o pentecostalismo, com o islamismo e com o candomblé.

Além disso, a CNBB esforça-se para criar estruturas internas que incentivem o diálogo. Orienta para que cada um dos seus 17 Regionais e todas as dioceses do Brasil, tenham uma comissão ou um setor de diálogo ecumênico e inter-religioso; e publica orientações sobre como viver o ecumenismo na evangelização ${ }^{16}$. É digna de nota, ainda, a decisão da CNBB realizar, já por

\footnotetext{
${ }^{15}$ Alguns exemplos são encontrados no "Relatório dos encontros interregionais de ecumenismo - 1970" (Biblioteca INP, D, 11748, 21/11/80, Arquivo da CNBB); no seminário, em 1965, sobre "O diálogo ecumênico no Brasil pelos meios audiovisuais: rádio, TV" (Biblioteca INP, D, n. 11742, 21/11/80); no seminário, em 1975, do "Comitê AD HOC Latino Americano para Projetos Ecumênicos" (Biblioteca INP, D, 11745, 21/11/80, Arquivo da CNBB); nas relações com a Sociedade Bíblica do Brasil (Biblioteca INP, D, n. 11757, 21/11/80, Arquivo da CNBB).

${ }^{16}$ Diretório Ecumênico "Ad totam ecclesiam" e sua complementação para o Brasil, São Paulo, Paulinas, 1967; Guia Ecumênico - Estudos da CNBB 21, São Paulo, Paulinas, 1979; "O ecumenismo dentro de nossa pastoral de conjunto", in CNBB, Biblioteca INP, D, n. 11747, 21/11/80. Arquivo da CNBB. Mimeo; Pela Unidade dos Cristãos - Guia Ecumênico Popular - Estudos da CNBB 28, São Paulo, Paulinas, 1986; O que é ecumenismo? Uma ajuda para trabalhar a exigência do diálogo, São
} 
três vezes, a "Campanha da Fraternidade Ecumênica", em parceria com as Igrejas-membro do CONIC (nos anos(2000, 2005 e 2010) - e espera-se nova Campanha da Fraternidade Ecumênica em $2015^{17}$.

b) Horizonte teológico: esses elementos históricos estão sustentados por motivações teológicas. $\mathrm{O}$ ecumenismo é motivado por princípios de fé e não por fatores circunstanciais. Esses princípios são contextualizados na realidade local. E se concretizam nas iniciativas que impulsionam o diálogo, a convivência pacífica, a cooperação e a unidade dos cristãos. A Igreja católica no Brasil incentiva para que os seminários e as faculdades de teologia fortaleçam o estudo do diálogo ecumênico e interreligioso; realiza encontros anuais com professores de ecumenismo de todo o país; exorta as dioceses para que possibilitem a formação ecumênica dos agentes de pastoral (algumas chegaram a criar escolas ou cursos permanentes de ecumenismo, como é o caso das dioceses de Joinville e Blumenau, em Santa Catarina); participa ativamente da comissão teológica do CONIC, onde são estudadas questões doutrinais pertinentes à unidade cristã no Brasil; e sempre envia delegados nos seminários promovidos tanto pelo CONIC quanto pelas comissões nacionais de diálogo bilateral, onde se estudam questões teológicas e pastorais do ecumenismo, como a doutrina da justificação (Comissão Nacional Católica-Luterana, 1998), a hospitalidade eucarística (CONIC, 1999), os ministérios (Comissão Nacional Católica-Luterana, 2002), missão e ecumenismo (CONIC, 2007), eclesiologia ecumênica (Comissão Nacional Católica-Luterana, 2010), o diálogo interreligioso (CONIC, 2011).

Por essas atividades, entre outras, a Igreja católica no Brasil desenvolve a consciência da busca da unidade cristã como uma convicção teológica, de fé. E está aberta às demais tradições eclesiais para o diálogo teológico sincero e transparente acerca dos elementos que constituem a unidade da Igreja, a fé, os sacramentos, os ministérios, a missão.... O horizonte teológico do ecumenismo é fundamental para sustentar os passos nos caminhos da unidade cristã ${ }^{18}$.

Paulo, Paulinas, 1997. Para o diálogo interreligioso: Guia para o Diálogo Inter-Religioso - Estudos da CNBB 52, São Paulo, Paulinas, 1987; A Igreja e os Novos Grupos Religiosos - Estudos da CNBB 68, São Paulo, Paulinas, 1993.

${ }_{17}$ Para aprofundar o posicionamento ecumênico da CNBB, ver: Wolff, E., O Ecumenismo no Brasil - Introdução ao pensamento ecumênico da CNBB, São Paulo, Paulinas, 1999.

${ }^{18}$ Wolff, E., Caminhos do Ecumenismo no Brasil, São Paulo, Paulus, 2002, 155-344. 
c) Horizonte pastoral: a razão de se buscar a unidade da Igreja é o testemunho da verdade do Evangelho para o mundo. Ecumenismo e evangelização se implicam mutuamente: "que todos sejam um... para que o mundo creia" (Jo 17, 21). O horizonte pastoral do ecumenismo no Brasil manifesta-se por três principais elementos: 1) a necessidade da cooperação intereclesial diante dos gigantescos desafios da evangelização; 2) a vinculação entre unidade cristã e promoção humana; 3) o redimensionamento do universo semântico de "ecumenismo", inserindo o ideal da unidade cristã num horizonte mais amplo, do diálogo cultural e interreligioso. Na sociedade brasileira o horizonte pastoral do ecumenismo mostra o seu caráter profético, buscando o testemunho da unidade em meio a sociedade dividida entre classes sociais, etnias, gêneros e culturas que vivem tensões e separações profundas ${ }^{19}$.

É importante observar, ainda, que as iniciativas de caráter oficial somam-se aquelas que acontecem espontaneamente nas comunidades dos fiéis, onde é priorizada a colaboração ecumênica no âmbito da promoção humana, da justiça social, do bem-estar geral e da moralidade pública e privada. Situam-se aqui a atuação dos organismos ecumênicos autônomos, os quais possibilitam um processo de aprendizagem, de conhecimento mútuo, de troca de experiências, fortalecendo a consciência e a prática da solidariedade através da realização de iniciativas missionárias e diaconais peculiares ${ }^{20}$. Desse modo, também no Brasil a Igreja católica busca desenvolver a dimensão ecumênica da evangelização. Os caminhos do diálogo local estão sendo abertos passo a passo. E mesmo se por vezes os passos dados são incertos, tem-se, ao menos, a certeza de que se está no caminho.

\section{Desafios do ecumenismo no Brasil}

O contexto no qual situa-se o diálogo ecumênico no Brasil é configurado por três principais horizontes: 1) $O$ cristianismo, onde encontram-se, de um lado, o pluralismo eclesial constituído pelas denominações consideradas "históricas" e, por outro lado, o pentecostalismo; 2) o pluralismo religioso

\footnotetext{
${ }^{19}$ Wolff, E., Caminhos do Ecumenismo no Brasil, 343-408.

${ }^{20}$ Alguns exemplos de organismos ecumênicos no meio popular: Centro Ecumênico de Evangelização, Capacitação e Assessoria - CECA (1973); Movimento de Fraternidade de Igrejas Cristãs - MOFIC (1977); Centro Ecumênico de Serviços à Evangelização e Educação Popular - CESEP (1983); Instituto de Educação Teológica da Bahia (1987), Centro de Estudos Ecumênicos de Florianópolis (1998), entre outros.
} 
formado, além do cristianismo, de um lado pelas expressões de fé mais antigas, como as religiões primitivas dos povos indígenas e africanos, o judaísmo o islamismo, o budismo e outras. De outro lado, estão os movimentos religiosos modernos, como o espiritismo, a Nova Era e outras de matriz oriental, como a Seicho-no-Iê; 3) a sociedade, configurada por uma diversidade de povos, raças, culturas e classes sociais que dificultam compreendê-la como um todo único, com conflitos que não poucas vezes desintegram o complexo social.

Nesse contexto, não é tarefa simples individuar os elementos que possibilitam a superação da divisão. É um desafio encontrar os parceiros do diálogo, o método e os conteúdos a serem trabalhados. E são poucos os espaços que oferecem real possibilidade para um diálogo profícuo. Além disso, os horizontes que configuram o contexto religioso plural fazem com que o diálogo assuma diversas direções, onde por vezes se desencontram tendências intra-cristãs e aquelas que defendem a superação de um "ecumenismo cristão" por um "macro-ecumenismo".

Por essas razões, entre outras, os caminhos até agora traçados pelo diálogo ainda não são consistentes. Entre as principais razões desse fato estão: o limitado número de pessoas e Igrejas que no Brasil aderem ao ecumenismo; a fragilidade das motivações para o diálogo, em seu conteúdo, método e resultados; o pouco esforço por parte das lideranças eclesiásticas - o que faz com que as iniciativas ecumênicas mais significativas provenham dos organismos ecumênicos populares, não poucas vezes à revelia das Igrejas; o clima de desconfiança que por vezes se manifesta sobre as reais motivações dos que dialogam. Em geral, há pouca disponibilidade ao diálogo, sobretudo no amplo contexto das comunidades pentecostais, em setores do protestantismo histórico e nos movimentos eclesiais católicos. Acresce-se a esses desafios a realidade social de divisão e a pluralidade do campo religioso brasileiro; a intensa prática do proselitismo, ainda vigente; a frágil unidade interna de algumas denominações; a perda de sentido da pertença eclesial; a privatização da prática de fé dos cristãos; o trânsito dos cristãos de uma confissão para outra em busca de uma experiência religiosa satisfatória; o hibridismo dos símbolos religiosos.

Não existem receitas prontas para a superação desses desafios. Mas para enfrentá-los é necessário compreender que o contexto religioso plural exige um diálogo que seja universal, do qual ninguém está excluído; diferenciado, respeitando as peculiaridades de cada parceiro; e reciprocamente aberto, no sentido que ecumenismo não se faz por via de mão única ${ }^{21}$. Para colocar-se

${ }^{21}$ WolfF, E., Caminhos do Ecumenismo no Brasil,175. 
nesse diálogo, a Igreja precisa libertar-se, com pobreza evangélica, de cada superestrutura autoritária e de poder, sentando-se à mesa em igualdade de condições, como atitude de profecia ecumênica.

Em termos práticos, isso implica no fortalecimento das iniciativas ecumênicas em algumas principais direções: no cotidiano dos fiéis, onde já existe uma prática espontânea de aproximação na vida do povo cristão, sobretudo nos meios onde se promove a dignidade humana, a justiça e a paz; a consolidação das iniciativas institucionais, como a Dimensão 5 da CNBB, as comissões bilaterais de diálogo, as comissões diocesanas, regionais e nacional; a formação ecumênica, tanto dos ministros ordenados quanto das comunidades dos fiéis; a conjugação entre o teológico e o pastoral na reflexão e na prática ecumênicas; a participação efetiva nos organismos ecumênicos, onde melhor se explicita a comunhão na solicitude pastoral.

\section{Que unidade se busca?}

Surge, enfim, a questão: após a consideração da orientação e da prática ecumênicas da Igreja católica, em que consiste a unidade buscada? Quais seus elementos constitutivos?

O diálogo ecumênico tem se debruçado sobre essa questão, apresentando as mais variadas propostas sobre a forma da unidade futura da Igreja ${ }^{22}$. Também as Igrejas e os teólogos dão sua contribuição ${ }^{23}$. Não se trata de

\footnotetext{
${ }^{22}$ Dentre as quais: unidade orgânica, que se realizaria pela colaboração, a intercomunhão e seria corporativa, não descartando a possibilidade da fusão de estruturas eclesiásticas (Assembléia de Fé e Constituição, Edimburgo, 1937); unidade na diversidade, cuja visibilidade não implicaria numa instituição eclesial única e centralizada, nem numa uniformidade de expressões e linguagem, mas num consenso sobre o conteúdo da fé, dos sacramentos, dos ministérios, do testemunho e do serviço comum (Assembléia do CMI, em Nova Delhi, 1961); comunidade conciliar de Igrejas locais, contendo cada uma a totalidade da Igreja de Jesus Cristo (Assembléia do CMI, em Nairobi, 1971) (Enchiridion Oecumunicum, vol I, 752-771; VercruYsse, Jos, E., Introduzione alla Teologia Ecumenica,106-118) .

${ }^{23}$ A Federação Luterana Mundial propõe a unidade como diversidade reconciliada, mantendo as diferenças entre as Igrejas, mas tirando-lhes o potencial agressivo e divisionista. Das propostas dos teólogos, destacam-se: Unidade pela diversidade, entendendo que as diferenças possuem um potencial enriquecedor da unidade (Culmann, Oscar, L'Unité par la diversité - son fondement et le problème de sa realisation, Paris, Cerf, 1986); Comunhão de Igrejas, por um processo de reunificação, permanecendo cada uma fiel ao carisma recebido (RAHner, K.-Fries, H., La uniós de las Iglesias - Una possibilidad real, Barcelona, Herder, 1987); Unidade de comunhão, salvaguardando a pluralidade de Igrejas como valor em si, como parece indicar o próprio texto do novo testamento (DUQUOC, Christian, Iglesias Provisionales - Ensayo de eclesiología ecuménica, Madrid, Cristianidad, 1986).
} 
analisar aqui essas diferentes propostas e nem mesmo de optar por alguma delas. Cabe observar, contudo, que algumas já foram superadas pelos progressos do diálogo, como é o caso da unidade orgânica. $O$ fundamental é considerar que elas se encontram no mundo das "possibilidades" para o futuro do ecumenismo e da Igreja. E nesse sentido tratam-se de hipóteses, algumas mais plausíveis do que outras de acordo com as circunstâncias em que se desenvolve o diálogo. Só Deus sabe como viverão os cristãos no futuro da Igreja unida.

Qualquer proposta de unidade da Igreja precisa conter três principais elementos:

1) a dimensão sacramental, que apresenta a unidade como sinal da comunhão que Deus é em si mesmo e que deseja para toda a humanidade. A unidade é, assim, um sinal "a fim de que o mundo creia" (Jo 17, 21). Daqui a necessidade de dar uma "forma histórica" à unidade, pois ela não é abstração ou algo puramente espiritual. Para ser sacramento, a unidade manifesta-se por alguma estrutura visível, material, garantida por elementos que a sustentam historicamente. E essa estrutura visível sinaliza o invisível.

2) priorizar a comunhão no conteúdo mais do que na forma, tal como expressou João XXIII ao abrir o Concílio, acerca da compreensão da verdade da fé cristã e da Igreja. Fugindo do uniformismo, a unidade acontece na diversidade, uma vez que a comunhão "nas coisas necessárias" permite a liberdade na espiritualidade, na disciplina, na liturgia e na teologia (UR 4). É uma "unidade plural" 24 , cuja natureza manifesta-se no horizonte da comunhão que reconcilia e integra as diferenças. Comunhão em certa medida e em certos aspectos já existente, mas em vias de crescimento em elementos sobre a fé, os sacramentos, a comunhão com os pastores e o serviço aos necessitados, sobretudo aos injustamente empobrecidos. Em torno a esses elementos, é que se pensa a unidade do Povo de Deus na assembléia santa - Ekklesia - sendo a koinonia a sua natureza, missão e fim.

3) O sentido de "unidade" não é unívoco e indica, ao menos, três horizontes: inter-eclesial, interreligioso, social. Mas mesmo que, etimologicamente, o universo semântico de "ecumene" extrapole o horizonte cristão, na Igreja católica e no movimento ecumênico esse termo designa a busca da unidade entre cristãos, com a finalidade de reconstituir a visibilidade histórica da unidade da Igreja (UR 4). Isso,

${ }^{24}$ Wolff, Elias, A Unidade da Igreja, Paulus, 2007. 
contudo, em nada impede de se construir uma compreensão comum e atualizada de "ecumene", em meio aos processos econômicos, sociais, culturais e políticos que afetam a vida dos cristãos e da humanidade inteira. Aqui a importância e riqueza da criatividade nas formas de cooperação ecumênica, propostas tanto pelos organismos ecumênicos como pelos líderes eclesiásticos. No mundo atual, dividido por fatores econômicos, políticos, culturais e de gênero, além dos religiosos, num contexto em que a vida humana é ameaçada por estruturas injustas, o ecumenismo assume ares de profecia a favor da comunhão na fraternidade e na justiça evangélicas. Sem perder a especificidade cristã, a prática ecumênica orienta-se à fidelidade ao projeto divino de reconciliar a diversidade da oikoumene, como reconciliação da humanidade (Ef 2,14-16). Desse modo, a unidade deve significar diálogo, parcerias, alianças dentro e fora do mundo cristão. Em sua profundidade mais íntima, o ecumenismo designa a realidade salvífica do povo de Deus conformado - pelos modos que o Espírito conduz - no corpo de Cristo, sua Igreja.

\section{Concluindo: passos para continuar no caminho}

Para a Igreja católica, a superação dos obstáculos na busca da unidade cristã exige o resgate do Concílio Vaticano II e sua intrínseca vinculação com o ecumenismo. Isso possibilita intensificar os esforços ecumênicos da Igreja universal e local em várias direções, estreitando o diálogo entre as lideranças eclesiásticas e os organismos ecumênicos, entre o caminho teológico-doutrinal e o pastoral, entre a busca da unidade na fé e os esforços pela promoção humana. O Concílio orienta e exige da Igreja que dê passos firmes nas trilhas ecumênicas, fortalecendo o compromisso com a unidade dos cristãos e de todo o gênero humano a partir do desenvolvimento de capacidades novas para se relacionar, estabelecer compromissos, construir consensos, coordenar ações e partilhar recursos sobre bases organizacionais, administrativas e operativas explícitas e transparentes. Isso exige renovar e revigorar a participação no movimento ecumênico. Somente assim pode-se chegar a novos consensos e manter a disposição para escutar e se colocar no lugar do outro. Para isso é preciso abertura e sensibilidade para as importantes mudanças que se produzem no âmbito das Igrejas e do movimento ecumênico. Exige, ainda, que a Igreja e os organismos a ela vinculados realizem um esforço decidido por explicitar as convicções teológicas que fundamentam o compromisso ecumênico. Há uma prática a ser definida que seja simultaneamente eclesial e ecumênica, criando, assim, uma visão ecumênica como princípio de vida, radicada na vivência comunitária da fé. 
Concretamente, isso significa: 1) intensificar a recepção dos resultados do diálogo entre as Igrejas e organismos ecumênicos, tanto no nível da informação quanto da circulação, como um processo de assimilação vital, urgente e necessária; 2) organizar a vida das comunidades num verdadeiro "espírito" e "método" ecumênicos, na pastoral, na espiritualidade, na catequese, nas instituições e estruturas; 3) acreditar e investir no diálogo que acontece pelos organismos e comissões, a partir do respeito das recíprocas identidades e tradições; 4) buscar com sinceridade a reconciliação evangélica, demonstrando sincera abertura para compreender a teologia e a prática das "Igrejas irmãs"; 5) investir em "estruturas ecumênicas", como as comissões diocesanas, regionais e nacionais; 6) investir na "formação ecumênica", tanto dos ministros ordenados quanto das comunidades dos fiéis; 7) ter claro os horizontes do diálogo, estabelecendo metas a serem atingidas, sobretudo nos horizontes doutrinal, pastoral e espiritual.

Concluindo, para ser fiel ao Concílio Vaticano II, a Igreja católica precisa tomar a sério o ecumenismo como o seu modo de ser e agir na história atual. $\mathrm{O}$ ecumenismo precisa tornar-se um fato eclesial, ou seja, envolver a Igreja como um todo, para que a Igreja seja, por sua vez, uma realidade de unidade. Somente assim pode-se ter uma coerente e corajosa fidelidade ao evangelho do Reino que ela crê e proclama, frequentemente pouco crível porque pobre de comunhão.

\section{Referências Bibliográficas}

ALBERIGO, Giuseppe, org., História dos Concílios Ecumênicos, Paulus, 1995, 394.

CNBB, Comunicado Mensal, jan/fev., 148-149 (1965), 11.

CNBB, Diretório Ecumênico "Ad totam ecclesiam" e sua complementação para o Brasil, São Paulo, Paulinas, 1967

CNBB, Guia Ecumênico - Estudos da CNBB 21, São Paulo, Paulinas, 1979

CNBB, "O ecumenismo dentro de nossa pastoral de conjunto", in CNBB, Biblioteca INP, D, n. 11747, 21/11/80. Arquivo da CNBB. Mimeo

CNBB, Pela Unidade dos Cristãos - Guia Ecumênico Popular - Estudos da CNBB 28, São Paulo, Paulinas, 1986

CNBB, O que é ecumenismo? Uma ajuda para trabalhar a exigência do diálogo, São Paulo, Paulinas, 1997

CNBB, Para o diálogo interreligioso: Guia para o Diálogo Inter-Religioso Estudos da CNBB 52, São Paulo, Paulinas, 1987

CNBB, A Igreja e os Novos Grupos Religiosos - Estudos da CNBB 68, São Paulo, Paulinas, 1993 
CULMANN, Oscar, L'Unité par la diversité - son fondement et le problème de sa realisation, Paris, Cerf, 1986

DUQUOC, Christian, Iglesias Provisionales - Ensayo de eclesiología ecuménica, Madrid, Cristianidad, 1986

Enchiridion Oecumenicum, Bologna, EDB, vol. I, 1988 e vol. III, 1995.

Instrução do Santo Ofício, De motione ecumenica, de 20/12/1949.

JOÃO PAULO II, Carta encíclica Ut Unum Sint, Paulinas, 1996.

JOS. E., Introduzione alla Teologia Ecumenica, Casale Monferrato, PIEMME, 1992, 64.

LEÃO XIII , encíclicas Praeclara gratulationis (1894) e Satis Cognitum (1896)

PIO X, encíclicas Ex quo (1926) e Pascendi dominici gregis (1907)

PIO XI , encíclicas Mortalium animos (1928)

PIO XII, encíclicas Mystici corporis (1943)

RAHNER, K.-FRIES, H., La uniós de las Iglesias - Una possibilidad real, Barcelona, Herder, 1987

ROCHA, Z.B., "Ecumenismo: avanços e recuos", Revista Eclesiástica Brasileira, 241 (2001) 85-100. Aqui, 87)

STRANSKY, Tom., "Pontificio Consiglio per la Promozione dell'Unità dei Cristiani", in Dizionario del Movimento Ecumenico, Bologna, EDB, 1994, 860 .

WOLFF, Elias, A Unidade da Igreja, Paulus, 2007.

WOLFF, E., O Ecumenismo no Brasil-Introdução ao pensamento ecumênico da $C N B B$, São Paulo, Paulinas, 1999.

WOLFF, E., Caminhos do Ecumenismo no Brasil, São Paulo, Paulus, 2002, 155-344.

WOLFF, E., Caminhos do Ecumenismo no Brasil, 343-408.

WOLFF, E., Caminhos do Ecumenismo no Brasil,175.

Elias Wolff

Presbítero da Diocese de Lages - SC

Professor no Instituto Teológico de Santa Catarina - ITESC Assessor da Comissão Episcopal Pastoral para o Ecumenismo e o Diálogo Interreligioso - CNBB elias.wolff@itesc.org.br

Artigo Recebido em 14/10/2011

Artigo Aprovado em 30/11/2011 